\title{
PERSEPSI MASYARAKAT TERHADAP AKAD JUAL BELI ONLINE PERSPEKTIF EKONOMI SYARIAH
}

\author{
Daharmi Astuti* \\ *Fakultas Agama Islam (FAI) Universitas Islam Riau (UIR) Pekanbaru \\ Jl. Kaharuddin Nasution No. 113 Perhentian marpoyang Pekanbaru 28284 \\ e-mail : daharmi_astuti@fis.uir.ac.id
}

\begin{abstract}
Abstrak : Penelitian ini dilatar belakangi maraknya perkembangan sistem teknologi informasi melalui media elektronik dan media sosial. Perkembangan sistem ini juga menambah sistem dan model akad transaksi jual beli. Dalam transaksi tersebut di satu sisi memberi kemudahan dan efisiensi, akan tetapi di sisi yang lain akad transaksi jual beli online menimbulkan berbagai permasalahan yang bertentangan dengan prinsip Ekonomi Syariah. Oleh karena itu, penulis tertarik untuk mengkaji persepsi masyarakat terhadap akad jual beli online dilihat dari sudut pandang Ekonomi Syariah. Penelitian ini dikhususkan kepada persepsi ibu-ibu majelis taklim BKMT Kota Pekanbaru untuk mengetahui persepsi masyarakat terhadap akad jual beli online, karena mereka merupakan entitas masyarakat yang cenderung menggunakan transaksi akad jual beli online. Hasil penelitian menunjukkan tanggapan responden mengenai persepsi masyarakat terhadap akad jual beli online perspektif Ekonomi Syariah di BKMT Kota Pekanbaru menyatakan "setuju" dengan persentase 42,78\%. Maka dapat disimpulkan bahwa persepsi masyarakat terhadap akad jual beli online di BKMT Kota Pekanbaru dapat dikatakan "cukup baik". Penelitian ini diharapkan dapat menjadi informasi model transaksi akad jual beli yang aktual, dan dapat menjadi rujukan/referensi akad jual beli online yang sesuai menurut pandangan Islam.
\end{abstract}

Kata Kunci: Persepsi, Akad, Jual Beli, Digital, E-commerce 


\section{PENDAHULUAN}

Perkembangan teknologi informasi dan telekomunikasi menyebabkan dunia menjadi tanpa batas (boderless) dan menyebabkan perubahan sosial secara signifikan berlangsung demikian cepat. Namun demikian, walaupun pada awalnya diciptakan untuk menghasilkan manfaat positif, tetapi juga memungkinkan digunakan untuk hal negatif.

Internet, jaringan terbesar komputer di dunia pada saat ini digunakan oleh berjuta-juta orang yang tersebar di segala penjuru dunia. Internet membantu mereka sehingga dapat berinteraksi, berkomunikasi, belajar bahkan melakukan perdagangan dengan orang lain dari segala penjuru dunia dengan mudah, cepat dan murah. Penggunaan internet untuk berbagai macam kegiatan ini sudah berbeda jauh dengan tujuan semula adanya jaringan ini. Sejak bisnis terkait dengan komputer dan sistem jaringan global atau yang disebut dengan internet muncul ke permukaan, maka terjadi suatu momentum perubahan terhadap aspek kehidupan masyarakat terutama di dalam bidang transaksi perdagangan.

Transaksi yang dilakukan dengan cara konvensional yakni sistem perdagangan dimana penjual dan pembeli bertemu langsung. Barang yang akan dijual berada di dekat pembeli, beralih kepada sistem online yang kebalikan dari jual beli yang biasanya (konvensional) dimana pembeli dan penjual tidak bertemu langsung dan barang yang diperjual belikan hanya berbentuk gambar atau tulisan yang menjelaskan spesifikasi dari barang yang akan dijual. Hal ini mengakibatkan transaksi dapat dilakukan setiap saat, dimana saja, dengan cara mengakses sistem produk yang diinginkan dalam jaringan internet.

Internet dalam dunia bisnis mau tidak mau telah merambah hingga terjadi transformasi ruang perdagangan di dunia nyata, tetapi ruang perdagangan di dunia maya juga turut dirambah. Teknologi internet mempunyai pengaruh yang cukup besar terhadap perekonomian dunia. Internet membawa perekonomian dunia memasuki babak baru yang lebih popular dengan istilah Digital Economic atau perekonomian digital. Makin banyak kegiatan perekonomian dilakukan melalui media internet. Perdagangan misalnya, semakin banyak mengandalkan $e$ commerce sebagai media transaksi $E$ commerce pada dasarnya adalah merupakan suatu kontak transaksi perdagangan antara penjual dan pembeli dengan menggunakan media internet. Jadi, proses pemesanan barang, pembayaran transaksi hingga pengiriman barang dikomunikasikan melalui internet. E-commerce tidak hanya memberikan kemudahan bagi konsumen, namun perkembangan ini memudahkan produsen dalam memasarkan produk yang berpengaruh pada penghematan biaya dan waktu. Melalui e-commerce semua formalitas-formalitas yang biasa digunakan dalam transaksi konvensional dikurangi, di samping tentunya konsumen memiliki kemampuan untuk mengumpulkan dan membandingkan informasi seperti barang dan jasa secara lebih leluasa tanpa dibatasi oleh batas wilayah (Masyur \& Gultom, 2005: 144).

Pelaksanaan jual beli online dalam prakteknya menimbulkan beberapa permasalahan, misalnya pembeli yang seharusnya bertanggung jawab untuk membayar sejumlah harga dari produk atau jasa yang dibelinya, tetapi tidak melakukan pembayaran. Bagi para pihak yang tidak melaksanakan tanggung jawabnya sesuai akad yang telah disepakati dapat digugat oleh pihak yang merasa dirugikan untuk mendapatkan ganti rugi.

Berbicara pada kompilasi hukum Ekonomi Syariah, suatu jual beli tidak sah bila tidak terpenuhi dalam suatu akad tujuan syarat yaitu (Mardani, 2012: 104105):

1. Saling rela antara kedua belah pihak 
2. Pelaku akad adalah orang yang dibolehkan melakukan akad, yaitu orang yang telah baligh, berakal dan mengerti.

3. Harta yang menjadi objek transaksi telah dimiliki sebelumnya oleh kedua pihak.

4. Objek transaksi adalah barang yang dibolehkan agama.

5. Objek transaksi adalah barang yang biasa diserah terimakan

6. Objek jual beli diketahui oleh kedua belah pihak saat akad.

7. Harga harus jelas saat transaksi.

Apabila dipenuhi dari ketujuh syarat sahnya akad tersebut, maka akad tersebut sah dan mengikat bagi para pihak.

Salah satu bagian dari komponen masyarakat adalah perempuan di mana berdasarkan kecendrungan transaksi jual beli online saat ini sangat diminati oleh kaum perempuan khususnya ibu-ibu majelis taklim saat mereka melakukan arisan atau kegiatan lainnya.

Permasalahannya setelah dilakukan survey kepada beberapa ibuibu yang sudah pernah melakukan jual beli online, sebagai contoh kejadian yang dialami konsumen tersebut saat melakukan jual beli online OLX. Penjual menawarkan 1 unit handphone, dimana handphone tersebut masih bagus tidak ada kerusakan apapun semua lancar jaya kata penjual dalam iklan OLX tersebut, konsumen akhirnya berminat untuk membelinya, tapi pada saat pertama menunggu untuk memakainya, handphone tersebut mengalami kerusakan pada layar karena sering berjalan sendiri (ujarnya).

Satu sisi pula jual beli ini sangat diminati di kalangan masyarakat, berdasarkan pra riset yang telah peneliti peroleh. Dalihnya jual beli ini mempermudah kami mencari barang apa saja yang diinginkan dengan mudah dan cepat dan tanpa masalah.

\section{TINJAUAN PUSTAKA \\ Definisi Persepsi}

Persepsi merupakan suatu proses yang didahului oleh proses penginderaan yaitu proses diterimanya stimulus oleh individu melalui alat indera (Walgio, 2002: 69). Persepsi didifenisikan sebagai suatu proses yang menggabungkan dan mengorganisir data-data indera kita (pengindraan) untuk dikembangkan sedemikian rupa sehingga kita dapat menyadari di sekeliling kita, termasuk sadar akan diri kita sendiri.

Persepsi merupakan proses pengolahan mental secara sadar terhadap stimulus sensori. Defenisi lain persepsi adalah stimulus yang diindera oleh individu, diorganisasikan kemudian diinterpretasikan sehimgga individu menyadari, mengerti tentang apa yang diindera. Persepsi dapat diartikan sebagai proses diterimanya rangsangan melalui panca indera dengan didahului oleh perhatian sehingga individu mampu mengetahui, mengartikan dan menghayati tentang hal yang diamati, baik yang ada di luar maupun di dalam individu.

\section{Faktor-faktor yang Mempengaruhi Persepsi}

External perception yaitu persepsi yang terjadi karena adanya rangsangan yang datang dari luar individu. Adapun faktor-faktor dari luar yang terdiri dari pengaruh-pengaruh lingkungan luar antara lain: 1) Intensitas, 2) Ukuran, 3) Keberlawanan atau kontras, 4)Pengulangan (repetition).

Self perception yaitu persepsi yang terjadi karena adanya rangsangan yang datang dari dalam individu. Dalam hal ini yang menjadi objek adalah dirinya sendiri. Beberapa faktor dari dalam diri seseorang mempengaruhi proses seleksi persepsi antara lain: 1)Belajar atau pemahaman, 2)Motivasi, 3)Kepribadian. 


\section{Definisi Jual Beli Menurut Islam}

Secara etimologi, jual beli adalah proses tukar menukar barang dengan barang. Kata bay' yang artinya jual beli termasuk kata bermakna ganda yang berseberangan, seperti halnya kata syiraa yang termaktub dalam Al-Qura'an surat Yusuf (12) ayat 20 dan surat Al-Baqarah (2) ayat 102 :

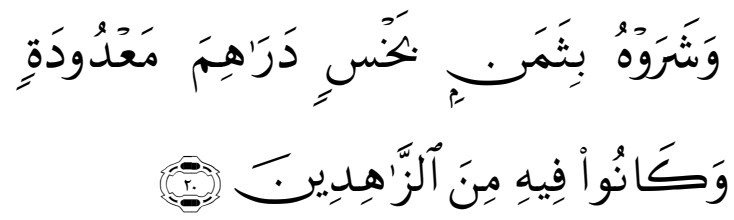

Artinya: "Dan mereka menjual Yusuf dengan harga yang murah, Yaitu beberapa dirham saja, dan mereka merasa tidak tertarik hatinya kepada Yusuf" (Departemen Agama RI, 2009).

Baik penjual maupun pembeli dinamakan baaîu dan bayyi un,musytarin dan syaarin. Secara terminologi, jual beli menurut ulama Hanafi adalah tukar-menukar maal (barang atau harta) dengan maal yang dilakukan dengan cara tertentu. Atau, tukar-menukar barang yang bernilai dengan semacamnya dengan cara yang sah dan khusus, yakni ijab-qabul atau mu'aathaa' (tanpa ijab qabul) dengan demikian, jual beli satu dirham dengan satu dirham tidak termasuk jual beli, karena tidak sah. Begitu pula, jual beli seperti bangkai, debu dan darah tidak sah, karena ia termasuk jual beli barang yang tidak disenangi. Menurut Imam Nawawi dalam kitab Majmu'mendefenisikan jual beli dengan tukar-menukar barang dengan barang dengan maksud memberi kepemilikan.(Wahbahaz-Zuhaili, 2011:25)

\section{Dasar Hukum Jual Beli}

Jual beli hukumnya boleh berdasarkan dalil-dalil Al-Qur`an dan sunnah, serta ijma: Adapun dalil AlQur`an dalam firman Allah SWT surat AlBaqarah (2) ayat 198, 275 dan 282 serta surat An-Nisaa' (4) ayat 29 :

Artinya: "Hai orang-orang yang beriman, janganlah kamu saling memakan harta sesamamu dengan jalan yang batil, kecuali dengan jalan perniagaan yang Berlaku dengan suka sama-suka di antara kamu. dan janganlah kamu membunuh dirimu. Sesungguhnya Allah adalah Maha Penyayang kepadamu" (Departemen Agama RI, 2009).

Adapun dalil dari sunnah, di antaranya sebagai berikut:

$$
\text { Artinya: "Nabi pernah }
$$

dipertanyakan tentang usaha apa yang paling baik itu? Beliau menjawab, 'usaha seseorang dengan hasil jerih payahnya sendiri dan berdagang yang baik".

Maksudnya, berdagang yang tidak mengandung unsur penipuan dan kebohongan."jual beli yang sah adalah jual beli yang berdasarkan kerelaan,"

Rasulullah saw, sendiri diutus ketika semua orang biasa melakukan perdagangan, lalu beliau tidak melarangnya, bahkan menetapkannya dengan sabda yang artinya :"Pedagang yang jujur dan amanat akan bersama para nabi, ash-shiddiqiin (orang-orang jujur), dan para syuhada." (HR Tarmidzi, hadist ini adalah hadist hasan).(Az-Zuhaili, 2011:26).

\section{Rukun dan Syarat Jual Beli}

Rukun jual beli menurut ulama Hanafiyah hanya satu, yaitu ijab (ungkapan membeli dan pembeli) dan qabul (ungkapan menjual dari penjual). Menurut mereka, yaitu menjadi rukun dalam jual beli itu hanyalah kerelaan (ridha/taradhi) kedua belah pihak untuk melakukan transaksi jual beli. Akan tetapi, karena unsur kerelaan itu merupakan unsur hati yang sulit untuk diindra sehingga tidak kelihatan, maka diperlukan indikasi yang menunjukan kerelaan kedua belah pihak yang melakukan transaksi jual beli menurut mereka boleh tergambar dalam ijab dan qabul, melalui cara saling memberikan barang dan harga barang (ta'athi). (Ghazaly, 2010:71)

Rukun jual beli ada 3 yaitu akad, ijab, kabul), orang yang berakad (penjual dan pembeli) dan ma'kud 'alaih (objek akad).

Adapun mayoritas ahli fiqih berpendapat bahwa jual beli memiliki 
empat rukun yaitu penjual, pembeli, pernyataan kata (ijab-qabul), dan barang. Pendapat mereka ini berlaku pada semua transaksi. (Az-zuhaili, 2011:28-29)

Menurut Jumhur ulama, jual beli menjadi kebiasaan, misalnya jual beli sesuatu yang menjadi kebutuhan seharihari tidak disyaratkan ijab dan Kabul.

\section{Jenis-Jenis Jual Beli}

Berdasarkan harga jual beli dibagi pula menjadi empat bagian yaitu, pertama; jual beli yang menguntungkan (Al Murabahah), kedua; jual beli yang tidak menguntungkan yaitu menjual harga dengan aslinya (At-Tauliyah), ketiga; jual beli rugi (Al- Khasarah), keempat adalah jual beli Al Musawah adalah penjualan yang menyembunyikan harga aslinya tetapi kedua orang yang akad saling meridhai, jual beliseperti inilah yang berkembang sekarang.

\section{Manfaat dan Hikmah Jual Beli}

Manfaat jual beli antara lain adalah sebagai berikut: 1)Jual beli dapat menata struktur kehidupan ekonomi masyarakat yang menghargai hak milik orang lan. 2)Penjual dan pembeli dapat memenuhi kebutuhannya atas dasar kerelaan atau suka sama suka. 3)Masing-masing pihak merasa puas. Penjual melepas barang dagangannya dengan ikhlas dan menerima uang, sedangkan pembeli memberikan uang dan menerima barang dagangan dengan puas pula. Dengan demikian, jual beli juga mampu mendorong untuk saling bantu antara keduanya dalam kebutuhan sehari-hari. 4)Dapat menjauhkan diri dari memakan atau memiliki barang yang haram (batil). 5)Penjual dan pembeli mendapat rahmat dari Allah swt. 6)Menumbuhkan ketentraman dan kebahagiaan.

Hikmah jual beli adalah menghindarkan manusia dari kesulitan dalam bermuammalah dengan hartanya. Seseorang memiliki harta di tangannya, namun dia tidak memerlukannya. Sebaliknya, dia memerlukan suatu bentuk harta, namun harta yang diperlukannya itu ada ditangan orang lain. Kalau seandainya orang lain yang memiliki harta yang diingininya itu juga memerlukan harta yang ada di tangannya yang tidak diperlukannya itu, maka dapat berlaku usaha tukar menukar yang dalam istilah berbahasa Arab disebut jual beli.

\section{Saksi Dalam Jual Beli}

Jual beli dianjurkan dihadapan saksi, berdasarkan firman Allah QS. AlBaqarah (02) ayat 282:

"Hai orang-orang yang beriman, apabila kamu bermu'amalah tidak secara tunai untuk waktu yang ditentukan, hendaklah kamu menuliskannya. dan hendaklah seorang penulis di antara kamu menuliskannya dengan benar. Dan janganlah penulis enggan menuliskannya sebagaimana Allah mengajarkannya, meka hendaklah ia menulis, dan hendaklah orang yang berhutang itu mengimlakkan (apa yang akan ditulis itu), dan hendaklah ia bertakwa kepada Allah Tuhannya, dan janganlah ia mengurangi sedikitpun daripada hutangnya. Jika yang berhutang itu orang yang lemah akalnya atau lemah (keadaannya) atau Dia sendiri tidak mampu mengimlakkan, Maka hendaklah walinya mengimlakkan dengan jujur. dan persaksikanlah dengan dua orang saksi dari orang-orang lelaki (di antaramu). Jika tak ada dua oang lelaki, Maka (boleh) seorang lelaki dan dua orang perempuan dari saksi-saksi yang kamu ridhai, supaya jika seorang lupa Maka yang seorang mengingatkannya. Janganlah saksi-saksi itu enggan (memberi keterangan) apabila mereka dipanggil; dan janganlah kamu jemu menulis hutang itu, baik kecil maupun besar sampai batas waktu membayarnya. yang demikian itu, lebih adil di sisi Allah dan lebih menguatkan persaksian dan lebih dekat kepada tidak (menimbulkan) keraguanmu. (Tulislah mu'amalahmu itu), kecuali jika mu'amalah itu perdagangan tunai yang kamu jalankan di antara kamu, Maka tidak ada dosa bagi kamu, (jika) kamu tidak menulisnya. dan persaksikanlah apabila kamu berjual beli; dan janganlah penulis dan saksi saling sulit menyulitkan. jika kamu lakukan (yang demikian), Maka 
Sesungguhnya hal itu adalah suatu kefasikan pada dirimu. dan bertakwalah kepada Allah; Allah mengajarmu; dan Allah Maha mengetahui segala sesuatu" (Departemen Agama RI, 2009).

Demikian ini, karena jual beli yang dilakukan dihadapan saksi dapat menghindarkan terjadinya perselisihan dan menjauhkan diri dari sikap saling menyangkal. Oleh karena itu, lebih baik dilakukan, khususnya bila barang dagangan tersebut mempunyai nilai yang sangat penting (mahal). Bila barang dagangan itu nilainya sedikit, maka tidak dianjurkan mempersaksikannya.

Adapun menurut Ibnu Qudamah, bahwa mendatangkan saksi dalam jual beli adalah kewajiban yang tidak boleh ditinggalkan. Pendapat ini diriwayatkan dari ibnu Abbas dan diikuti oleh Atha' dan Jabir.

berjual beli."

"Dan persaksikanlah apabila kalian

\section{Khiyar dalam Jual Beli}

Dalam jual beli berlaku khiyar. Khiyar menurut pasal 20 ayat 8 Kompilasi Hukum Ekonomi Syariah yaitu hak pilih bagi penjual dan pembeli untuk melanjutkan atau membatalkan akad jual jual beli yang dilakukan.

Khiyar terbagi kepada tiga macam, yaitu khiyar majlis, yaitu tempat transaksi, dengan demikian khiyar majlis berarti hak pelaku transaksi untuk meneruskan atau membatalkan akad selagi mereka berada dalam tempat transaksi dan belum berpisah. Khiyar syarat yaitu: kedua pihak atau salah satunya berhak memberikan persyaratan khiyar dalam waktu tertentu, dan khyar 'aib yaitu hak pilih untuk meneruskan atau membatalkan akad dikarenakan terdapat cacat pada barang yang mengurangi harganya. (Mardani:2011: 105).

\section{Bentuk-bentuk Bai' (jual beli)}

Dari berbagai tinjauan, bai' dapat dibagi menjadi beberapa bentuk. Berikut ini bentuk-bentuk bai': 1)Ditinjau dari sisi objek akad bai' yang menjadi: a)Tukar menukar uang dengan barang. Ini bentuk $b a^{\prime} i$ berdasarkan konotasinya. Misalnya: tukar menukar mobil dengan rupiah. b)Tukar menukar barang dengan barang, disebut juga dengan(barter). Misalnya tukar-menukar buku dengan jam. c)Tukar menukar uang dengan uang, disebut juga dengan sharf. Misalnya: tukar menukar rupiah dengan real. 2)Ditinjau dari cara menetapkan harga, $b a^{\prime} i$ dibagi menjadi:

a)Ba'i musawamah (jual beli dengan cara tawar menawar), yaitu jual beli dimana pihak penjual tidak menyebutkan harga pokok barang, akan tetapi menetapkan harga tertentu dan pokok barang dan membuka peluang untuk ditawar. b) $B a^{\prime} i$ amanah, yaitu dimana pihak penjual menyebutkan harga pokok barang lalu menyebutkan harga jual barang tersebut. $B a^{\prime} i$ jenis ini terbagi lagi menjadi tiga bagian: 1) Ba'i Murabahah, yaitu pihak penjual menyebutkan harga pokok barang dan laba. Misalnya: pihak penjual mengatakan,"Barang ini saya beli dengan harga Rp. 10.000.- dan saya menjual dengan harga Rp. 11.0000,- atau saya jual dengan laba 10\% dari modal". 2) Ba'i alWadh'iyyah, yaitu pihak penjual menyebutkan harga pokok barang atau menjual barang tersebut di bawah harga pokok. Misalnya, penjual berkata: "barang ini saya beli dengan harga Rp. 10.000,dan akan saya jual dengan harga Rp. 9.000,- atau saya potong $10 \%$ dari harga pokok". 3) Ba'i Tauliyah, yaitu penjual menyebutkan harga pokok dan menjualnya dengan harga tersebut. Misalnya, penjual berkata, "barang ibu saya beli dengan harga Rp. 10.000,- dan saya jual sama dengan harga pokok". (Mardani , 2011:109)

c)Salam. Salam adalah pembelian barang yang dilakukan dengan pembayaran di depan tetapi penyerahan barang tersebut dilakukan dikemudian hari. Transaksi jual beli salam sah apabila objek jual beli diketahui dengan detail jenis, karakteristik, harga, jumlah, tata cara pembayaran, dan tempat pembayaran. Dengan salam, pihak pembeli (al-muslam) akan mendapatkan barang pada saat 
diperlukan nanti dengan harga yang sudah ditetapkan dan pihak penjual (muslam ilaih) mendapatkan dana di depan yang digunakan untuk mengadakan barang (Hidayat, 52: 2011).

Salam adalah menjual sesuatu yang tidak dilihat zatnya, hanya ditentukan dengan sifat; barang itu ada di dalam pengakuan (tanggungan) si penjual. Misalnya penjual berkata,"saya jual kepadamu satu meja tulis dari jati, ukurannya $140 \times 100 \mathrm{~cm}$, tingginya $75 \mathrm{~cm}$, sepuluh laci, dengan harga Rp. 100.000,00." Pembeli pun berkata, saya beli meja dengan sifat tersebut dengan harga Rp. 100.000,00." Dia membayar uangnya sewaktu akad itu juga, tetapi mejanya belum ada. Jadi, salam ini merupakan jual beli utang dari pihak penjual, dan kontan dari pihak pembeli karena uangnya telah dibayarkan sewaktu akad.

\section{Syarat - syarat Salam}

Syarat-syarat jual beli salam yaitu: a. Uangnya hendaklah dibayar di tempat akad. Berarti pembayaran dilakukan lebih dulu. b. Barangnya jadi utang bagi penjual. c. Barangnya dapat diberikan sesuai waktu yang dijanjikan. Berarti pada waktu yang dijanjikan barang itu harus sudah ada. d.Barang tersebut hendaklah jelas ukurannya, baik takaran, timbangan, ukuran, ataupun bilangannya, menurut kebiasaan cara menjual barang semacam itu. e. Diketahui dan disebutkan sifat-sifat barangnya. Dengan sifat itu berarti harga dan kemauan orang pada barang tersebut dapat berbeda. Sifat-sifat ini hendaknya jelas sehingga tidak ada keraguan yang akan mengakibatkan perselisihan nanti antara kedua belah pihak (penjual dan pembeli). Begitu juga macamya, harus pula disebutkan, misalnya daging kambing, daging sapi, atau daging kerbau. f. Disebutkan tempat menerimanya, kalau tempat akad tidak layak buat menerima uang tersebut. Akad salam mesti terus, berarti tidak ada khiyar syarat. (Rasjid, 2012:294).

\section{Bentuk - bentuk Jual Beli yang dilarang}

Setiap transaksi jual beli yang memberi peluang terjadinya persengketaan, karena barang yang dijual tidak transparan, atau ada unsur penipuan yang dapat membangkitkan permusuhan antara bdua pihak bertransaksi, atau salah satu pihak menipu pihak lain, dilarang oleh Nabi Muhammad SAW, sebagai antisipasi terhadap munculnya kerusakan yang lebih besar (Qardhawi: 2000: 356).

Jual beli yang dilarang terbagi dua: pertama, jual beli yang dilarang dan hukumnya tidak sah (batal), yaitu jual beli yang tidak memenuhi syarat dan rukunnya, kedua, jual beli yang hukumnya sah tetapi ada beberapa faktor yang menghalangi kebolehan proses jual beli.

Jual beli yang belum jelas. Sesuatu yang bersifat spekulasi samar-samar haram untuk diperjualbelikan, karena dapat merugikan salah satu pihak, baik penjual, maupun pembeli. Yang dimaksud dengan samar-samar adalah tidak jelas, baik barangnya, harganya, kadarnya, masa pembayarannya, jual beli yang dilarang karena samar-samar antara lain: 1)Jual beli buah-buahan yang belum tampak hasilnya. Misalnya, menjual putik mangga untuk dipetik kalau telah tua/masak nanti. Termasuk dalam kelompok ini adalah larangan menjual pohon secara tahunan

2)Jual beli barang yang belum tampak. Misalnya menjual ikan di kolam/laut, menjual ubi/singkong yang masih ditanam, menjual anak ternak yang masih dalam kandungan induknya. 3)Jual beli bersyarat ialah jual beli yang ijab kabulnya dikaitkan dengan syarat-syarat tertentu yang tidak ada kaitannya dengan jual beli atau unsur-unsur yang merugikan dilarang oleh agama.. 4)Jual beli yang menimbulkan kemudaratan yaitu segala sesuatu yang dapat menimbulkan kemudaratan, kemaksiatan, bahkan kemusyrikan dilarang diperjualbelikan seperti jual beli patung, salib, dan buku-buku bacaan porno. Menjualbelikan barang-barang ini dapat 
menimbulkan perbuatan-perbuatan maksiat. 5)Jual beli karena dianiaya yaitu segala bentuk jual beli yang mengakibatkan penganiayaan hukumnya haram, seperti menjual anak binatang yang masih membutuhkan (bergantung) kepada induknya. Menjual binatang seperti ini, selain memisahkan anak dari induknya juga melakukan penganiayaan terhadap anak binatang ini. 6)Jual beli muhaqalah, yaitu menjual tanaman yang masih disawah atau ladang.

7)Jual beli mukhadharah, yaitu menjual buah-buahan yang masih hijau (belum pantas dipanen). Seperti menjual mangga yang masih kecil-kecil. 8)Jual beli mulamasah yaitu jual beli secara sentuh menyentuh. Misalnya, seseorang menyentuh sehelai kain dengan tangannya di waktu malam atau siang hari, maka orang yang menyentuh berarti membeli kain ini. 9)Jual beli munabadzah, yaitu jual beli secara lempar-melempar seperti seorang berkata:"lempar kepadaku apa yang ada padamu, nanti kulemparkan pula kepadamu apa yang ada padaku". 10)Jual beli muzabanah, yaitu menjual buah yang basah dengan buah yang kering. Seperti menjual padi kering dengan bayaran padi basah sedang ukurannya dengan ditimbang sehingga akan merugikan pemilik padi kering.

\section{Media Online}

Online adalah terhubung, terkoneksi, aktif dan siap untuk operasi, dapat berkomunikasi dengan atau dikontrol oleh komputer. Online ini juga biasa diartikan sebagai sesuatu keadaan dimana sebuah device (komputer) terhubung dengan device lain, biasanya melalui modem.

Media Online adalah media massa yang dapat kita temukan di internet sebagai media massa, media online juga menggunakan kaidah-kaidah jurnalistik dalam sistem kerja mereka. Media massa online tidak pernah menghilangkan media massa lama tetepi mensubtitusikannya. Media online merupakan tipe baru jurnalisme karena memiliki sejumlah fitur dan karakteristik dari jurnalisme tradisional. Fitur-fitur uniknya mengemuka dalam teknologinya, menawarkan kemungkinan-kemungkinan tidak terbatas dalam memproses dan menyebarkan berita (Kurnia, 2005:137)

Dalam perspektif studi media atau komunikasi massa, media online menjadi objek kajian teori media baru (neewe media), yaitu istilah yang mengacu pada permintaan akses ke konten (isi/informasi) kapan saja, dimana saja, pada saat perangkat digital serta umpan balik pengguna interaktif, partisipasi kreatif dan pembentukan komunitas sekitar konten media, juga aspek generasi "real time".

Jadi, bisa disimpulkan jual beli online adalah proses tukar menukar barang dengan barang yang terhubung, terkoneksi, aktif dan beroperasi melalui jaringan dengan media maya.

Transaksi jual beli di dunia maya atau e-commerce merupakan salah satu produk internet yang merupakan sebuah jaringan komputer yang saling terhubung antara satu dengan yang lain melalui media komunikasi. Model transaksi jual beli di dunia maya saat ini berkembang sangat pesat. Dalam transaksi di dunia maya, antara pihak yang bertransaksi tidak bertemu langsung, akan tetapi dapat berkomunikasi langsung, baik secara audio maupun audio visual.

Akad dalam transaksi elektronik di dunia maya berbeda dengan akad secara langsung. Transaksi elektronik biasanya menggunakan akad secara tertulis (Email, SMS dan sejenisnya) atau menggunakan lisan (via telepon) atau video seperti teleconference. Jual beli melalui media elektronik adalah transaksi jual beli yang dilakukan via teknologi modern sebagaimana disebutkan keabsahannya tergantung pada terpenuhi atau tidaknya rukun dan syarat yang berlaku dalam jual beli. Apabila rukun dan syarat terpenuhi maka transaksi semacam ini sah sebagai sebuah transaksi yang mengikat. Dan sebaliknya apabila tidak terpenuhi maka tidak sah. 
Suatu akad dilakukan dengan isyarat saja bisa sah, terlebih dengan menggunakan tulisan, gambar dan ilustrasi yang lebih jelas. Isyarat dalam akad pada dasarnya mempunyai kekuatan hukum sebagaimana penjelasan dengan lisan. Sementara mengenai syarat adanya barang dan uang sebagai pengganti harga barang, maka dalam transaksi jual beli via elektronik atau e-commerce tidak dilakukan secara langsung dalam dunia nyata. Dalam hal bentuk dan wujud barang menjadi objek transaksi, dalam $e$ commerce biasanya hanya berupa gambar (foto atau video) yang menunjukkan barang aslinya kemudian dijelaskan spesifikasi sifat dan jenisnya. Pembeli dapat dengan bebas memilih barang sesuai dengan spesifikasi yang diinginkan. Barang akan dikirim setelah uang dibayar. Mengenai sistem pembayaran atau penyerahan uang pengganti barang, maka umumnya adalah dilakukan dengan cara transfer. Bila sistem yang berlaku seperti ini, maka pada dasarnya jual beli ini adalah jual beli salam. Pembeli memilih barang dengan spesifikasi tertentu, kemudian membayarnya, setelah itu barang akan diserahkan atau dikirim kepada pembeli. Hanya saja dalam transaksi salam, uang yang dibayarkan di muka sebagaimana jual beli salam.

Apabila sistem salam yang dilaksanakan dalam jual beli via media elektronik (e-commerce), maka rukun dan syaratnya juga harus sesuai dengan transaksi salam. Rukun salam yaitu: a. Muslim (pembeli atau pemesan); b. Muslam ilaih (penjual atau penerima pesanan); c. Muslam fih (barang yang dipesan); d. Ra'sul mal (harga pesanan atau modal yang dibayarkan); e. Sighat ijab-qabul (ucapan serah terima).

Adapun mengenai syarat salam, secara umum sama dengan syarat akad jual beli, yaitu: barang yang dipesan merupakan sepenuhnya milik penjual, bukan barang najis dan bisa diserahterimakan. Hanya saja dalam akad salam tidak ada syarat bagi pemesan untuk melihat barang yang dipesan, ia hanya disyaratkan menentukan sifat-sifat dan jenis atau spesifikasi barang yang dipesan secara jelas. Beberapa ulama menentukan syarat transaksi jual beli yang dilakukan dengan perantara: a. Kesinambungan antara ijab dan qabul. Menurut jumhur, selain Syafi'iyah qabul tidak harus langsung. b. Qabul dlakukan di tempat sampainya ijab; c. Kesesuaian antara ijab dan qabul; d.Tidak adanya pengingkaran dari salah satu pihak yang bertransaksi.

Hukum transaksi via teknologi modern seperti telepon, handphone, tablet atau media internet lain telah dibahas pada muktamar VI Fikih Islam yang dilaksanakan di Jeddah Saudi Arabia Tanggal 14-20 Maret 1990. Melihat perkembangan teknologi modern yang berdampak pada segala bidang, termasuk transaksi perdagangan demi kecepatan kegiatan bisnis dan ekonomi lainnya, maka perlu diputuskan hukum tentang penggunaan media tersebut dalam perspektif fikih Islam. Hal ini tentunya dengan tetap berpegang pada persyaratan-persyaratan transaksi yang telah ditetapkan oleh fuqaha, baik transaksi secara lisan, tulisan maupun via surat, persyaratan bertemunya para pihak dalam satu forum (ruang dan waktu), kontekstualitas antara ijab dan qabul, tidak adanya maksud salah satu pihak untuk melakukan wanprestasi dan kesinambungan antara ijab dan qabul. Muktamar tersebut memutuskan sebagai berikut: a. Apabila transaksi telah dilakukan oleh dua pihak yang tidak bertemu langsung secara fisik, tidak saling melihat dan mendengar satu sama lain, serta hanya menggunakan perantara surat, faksmili atau internet, maka transaksi tersebut sah dan mengikat secara hukum dengan syarat kedua belah pihak saling memahami dan menerima maksud transaksi secara tepat; b. Apabila transaksi dilakukan oleh dua pihak yang berjauhan dengan perantara telepon atau media teknologi modern lainnya, maka transaksi kedua belah pihak tersebut berlaku sebagaimana transaksi yang 
dilakukan secara langsung (face to face); c. Apabila salah satu pihak melakukan wanprestasi terhadap transaksi yang dilakukan dengan alat teknologi modern tersebut dengan batasan waktu tertentu, maka dia tidak dapat menarik kembali transaksi yang telah dilakukan; d. Transaksi via teknologi modern tersebut tidak berlaku pada akad nikah, karena dalam akad nikah diisyaratkan adanya saksi, tidak berlaku pada tukar menukar, karena adanya syarat penyerahan dan jual beli inden, karena disyaratkan downpainment; e. Apabila terjadi pamalsuan, pengingkaran atau kekeliruan, maka hukum yang berlaku sama dengan transaksi yang dilakukan secara langsung (face to face). Dalam hal ini, dalam transaksi elektronik ada sistem pengawasan sebagai upaya untuk menjamin terpenuhinya hak para pihak yang melakukan transaksi. Sistem pengawasan ini dikenal dengan process control yang menjadi bagian dari proses transaksi elektronik.

Transaksi jual beli via media elektronik dianggap sebagai ittihad almajlis, sehingga akad jual beli tersebut sah, karena masing-masing muta'aqqidain saling mengetahui dan mengetahui obyeknya (al-mabi') sehingga tidak terjadi gharar (ketidakjelasan). Dengan demikian maka akan terealisasi ijab dan qabul yang didasari suka sama suka.

Iitihad al-majlis bisa bermakna ittihad al-zaman (satu waktu), ittihad almakan (satu lokasi) dan ittihad al-haiah (satu posisi). Perbedaan tempat dapat disatukan melalui media komunikasi modern, membuat tempat yang berjauhan bisa dianggap menyatu.

Berdasarkan berbagai pendapat ulama dan penjelasan di atas, maka cukup jelas bahwa transaksi perdagangan atau jual beli yang dilakukan via media elektronik hukumnya sah. Kecanggihan media elektronik dapat membuat suasana dalam dunia maya menjadi seolah nyata. Namun demikian, transaksi tersebut dikategorikan sebagai transaksi kinayah yang keabsahannya dan kekuatan hukumnya sama dengan transaksi yang dilakukan secara langsung (sarih).

\section{METODE}

Jenis penelitian ini adalah penelitian deskriptif. Jenis penelitian deskriptif adalah jenis penelitian yang disusun dalam rangka memberikan gambaran secara sistematis tentang persepsi ibu-ibu majelis taklim terhadap akad jual beli online di Kota Pekanbaru dengan menyajikan data berupa uraian tabel persentase dari jawaban responden.

Penelitian ini dilakukan di PD BKMT di Pekanbaru, Sedangkan waktu penelitiannya pada bulan Agustus sampai dengan November 2017. Dalam penelitian ini yang dijadikan populasi adalah ibu-ibu majelis taklim dari PD BKMT Kota Pekanbaru. Berdasarkan data PD BKMT Kota Pekanbaru memiliki 180 Permata dalam 12 Kecamatan. Setiap permata terdiri dari 1-3 kelompok gabungan musholla/masjid dengan jumlah yang tidak sama setiap kelompok. Oleh karena itu, dari 12 Kecamatan penulis mengambil 6 Kecamatan berdasarkan jumlah populasi terbanyak dan wilayah yang dianggap mewakili yaitu kecamatan Senapelan, Tenayan Raya, Bukit Raya, Marpoyan, Sail dan Rumbai Pesisir dengan masing-masing diambil 30 orang Ibu Majelis taklim yang berjumlah 2.700 orang.

Mengingat pentingnya persepsi terhadap jual beli online, maka penulis melakukan pengambilan sampel dengan menggunakan rumus Slovin, karena banyaknya jumlah populasi secara keseluruhan dari para ibu-ibu majelis taklim yang ada di Kota Pekanbaru tersebut (Muhammad, 2008:10).

Rumus: $n=\frac{N}{1+N(e)^{2}}$

Keterangan :

$\mathrm{n}=$ sampel

$\mathrm{N}=$ ukuran populasi

e=Nilai kritis (batas ketelitian) yang diinginkan (persen kelonggaran ketidaktelitian karena kesalahan penarikan sampel). 
Dalam penelitian ini jumlah populasi $(\mathrm{N})=2.700$ orang, dengan nilai kritis (e) sebesar 10\% maka ukuran sampel:

$$
\begin{aligned}
& n=\frac{2700}{1+2700(10 \%)^{2}} \\
& n=96
\end{aligned}
$$

Jadi sampel dalam penelitian ini adalah 96 orang dan teknik pengambilan sampel dalam penelitian ini adalah menggunakan random sampling, yaitu pengambilan sampel secara acak dimana anggota sampelnya mendapatkan kesempatan yang sama untuk dijadikan sampel.

Untuk melengkapi data yang diperlukan dalam penelitian ini metode pengumpulan data yang digunakan adalah: 1)Angket atau kuesioner yaitu daftar pertanyaan/pernyataan yang diberikan kepada ibu-ibu majelis taklim yang bersedia memberikan respons sesuai dengan permintaan pengguna, pengukuran variabel dilakukan dengan menggunakan skala lima alternatif pilihan (Skala Likert). Setiap variabel diberikan skor penilaian sebagai berikut: (SS) Sangat Setuju $=$ Skor 5, (S) Setuju = Skor 4, (N)Netral= Skor 3, (TS)Tidak Setuju= Skor 2, (STS) Sangat Tidak Setuju = Skor 1. 2)Dokumentasi yaitu penulisan akan menyimpulkan dari bahan-bahan dokumentasi yang berhubungan dengan masalah yang diteliti.

\section{HASIL}

\section{Sejarah singkat BKMT Provinsi Riau}

Sejarah berdirinya BKMT Wilayah adalah hasil MUBES IV di Jakarta pada tanggal 2 - 6 Juli 1996. Sebagai utusan yang diberi mandat oleh Pemda Riau pada waktu itu adalah : Hj. Roslaini Ismail Suko (unsur wanita Riau), Hj. Rasini Ch Osman (Ketua IMTI Kota Pekanbaru), Hj. Mahanum HS, BA (Sekretaris IMTI Kota Pekanbaru), Drs. H. Muchtar Samad (Kakanwil Depag), Drs. H. Gafar Usman (staf Kanwil Depag) serta H. Anshar Muried, SH (staf Kanwil Depag). Dalam laporan ketua umum PP BKMT pada
MUBES tersebut menyampaikan bahwa BKMT yang belum terbentuk di 3 Provinsi salah satunya adalah Provinsi Riau.

Untuk merespon himbauan Ketua Umum BKMT Pusat itulah, maka utusan MUBES BKMT dari Provinsi Riau sekaligus sebagai tim formatur berinistaif mengadakan rapat pada tanggal 19 September 1997 / 17 Jumadil Awal 1418 $\mathrm{H}$ di Kediaman Walikota (rumah $\mathrm{Ibu} \mathrm{Hj}$. Rasini / istri Walikota. Hasil rapat tersebut mendukung pembentukan berdirinya BKMT Wilayah Riau dan tersusun calon kepengurusan yang diambil dari kalangan ibu-ibu.

Atas prakarsa tim formatur dengan dukungan moril Kakanwil Depag Provinsi Riau Bapak Drs. H. Rasyid Hamidi serta restu Gubernur Riau Bapak Soeripto dan Ibu Murniati Soeripto maka dikukuhkanlah BKMT Riau serta kepengurusannya periode 1998 - 2001 (Periode Pertama) oleh Ketua Umum BKMT Pusat Ibu Dra. Hj. Tutty Alawiyah AS. Berdasarkan Surat Keputusan BKMT Pengurus Pusat. No. S-Kep/01/PPBKMT/II/1998 tanggal 18 Februari 1998 bertempat di Aula Gubernuran Jl. Diponegoro Pekanbaru. Adapun ketua terpilih saat itu adalah $\mathrm{Ibu} \mathrm{Hj}$. Roslaini Ismail Suko.

Pada tanggal 18 Februari 1998 barulah terwujud pelantikan PW / Pengukuhan PW BKMT Riau sekaligus hari itu merupakan HARI JADI BKMT RIAU. Adapun HARI JADI BKMT PUSAT jatuh pada tanggal 1 Januari 1981 / 25 Shafar $1401 \mathrm{H}$.

\section{Struktur Organisasi BKMT}

Dalam kepengurusan BKMT Provinsi Riau terdapat 5 bidang yaitu : 1)Bidang Organisasi dan Pengembangan Kelembagaan. 2)Bidang Dakwah / Buletin 3)Bidang Pendidikan dan Pelatihan, 4)Bidang Sosial Kemasyarakatan, 5)Bidang Usaha dan Kerjasama.

\section{PEMBAHASAN}

Penelitian ini merupakan penelitian statistik deskriptif yaitu penyajian data dengan tabel, diagram 
lingkaran, perhitungan rata-rata dan persentase. Dari data angket yang dikumpulkan dari responden, dibuat data rekapitulasi selanjutnya data ditransformasikan dari data kualitatif menjadi data kuantitatif dengan memberi skor pada angket. Kriteria jawaban dan skor digunakan

untuk mentransformasikan dari data kualitatif dari setiap indikator yang digunakan dalam konsep operasional.

Berikut hasil rekapitulasi dari 40 butir pernyataan melalui angket kepada responden pada penelitan tersebut:

Tabel. 1

Rekapitulasi Perhitungan Data Angket Responden Persepsi Masyarakat Terhadap Akad Jual Beli Online Perspektif Ekonomi Syariah

\begin{tabular}{|c|c|c|c|c|c|c|c|}
\hline \multirow{2}{*}{ No. } & \multirow{2}{*}{ Pernyataan } & \multicolumn{6}{|c|}{ Rekapitulasi Perhitungan Data Angket } \\
\hline & & SS & $\mathrm{S}$ & $\mathrm{N}$ & TS & STS & Jumlah \\
\hline 1 & 1 & 11 & 65 & 14 & 4 & 3 & 97 \\
\hline 2 & 2 & 12 & 63 & 16 & 6 & - & 97 \\
\hline 3 & 3 & 13 & 55 & 21 & 8 & - & 97 \\
\hline 4 & 4 & 20 & 63 & 10 & 4 & - & 97 \\
\hline 5 & 5 & 24 & 55 & 13 & 5 & - & 97 \\
\hline 6 & 6 & 25 & 61 & 7 & 4 & - & 97 \\
\hline 7 & 7 & 34 & 30 & 26 & 7 & - & 97 \\
\hline 8 & 8 & 30 & 30 & 20 & 17 & - & 97 \\
\hline 9 & 9 & 36 & 34 & 19 & 8 & - & 97 \\
\hline 10 & 10 & 28 & 38 & 18 & 13 & - & 97 \\
\hline 11 & 11 & 29 & 32 & 20 & 16 & - & 97 \\
\hline 12 & 12 & 24 & 38 & 22 & 13 & - & 97 \\
\hline 13 & 13 & 27 & 35 & 21 & 14 & - & 97 \\
\hline 14 & 14 & 24 & 22 & 35 & 20 & - & 97 \\
\hline 15 & 15 & 30 & 38 & 24 & 5 & - & 97 \\
\hline 16 & 16 & 40 & 30 & 10 & 10 & 7 & 97 \\
\hline 17 & 17 & 38 & 32 & 20 & 7 & - & 97 \\
\hline 18 & 18 & 22 & 48 & 22 & 5 & - & 97 \\
\hline 19 & 19 & 25 & 28 & 22 & 22 & - & 97 \\
\hline 20 & 20 & 28 & 38 & 20 & 11 & - & 97 \\
\hline 21 & 21 & 24 & 40 & 18 & 15 & - & 97 \\
\hline 22 & 22 & 24 & 38 & 20 & 15 & - & 97 \\
\hline 23 & 23 & 28 & 48 & 21 & - & - & 97 \\
\hline 24 & 24 & 20 & 48 & 29 & - & - & 97 \\
\hline 25 & 25 & 22 & 32 & 23 & 20 & - & 97 \\
\hline 26 & 26 & 32 & 48 & 17 & - & - & 97 \\
\hline 27 & 27 & 25 & 45 & 27 & - & - & 97 \\
\hline 28 & 28 & 26 & 39 & 32 & - & - & 97 \\
\hline 29 & 29 & 22 & 37 & 20 & 18 & - & 97 \\
\hline 30 & 30 & 18 & 24 & 35 & 20 & - & 97 \\
\hline 31 & 31 & 14 & 35 & 20 & 28 & - & 97 \\
\hline 32 & 32 & 40 & 48 & 9 & - & - & 97 \\
\hline 33 & 33 & 20 & 40 & 20 & 17 & - & 97 \\
\hline 34 & 34 & 34 & 44 & 10 & 9 & - & 97 \\
\hline
\end{tabular}




\begin{tabular}{|l|l|c|c|c|c|c|c|}
35 & 35 & 14 & 41 & 32 & 10 & - & 97 \\
\hline 36 & 36 & 54 & 30 & 13 & - & - & 97 \\
\hline 37 & 37 & 22 & 44 & 31 & - & - & 97 \\
\hline 38 & 38 & 32 & 58 & 7 & - & - & 97 \\
\hline 39 & 39 & 42 & 48 & 7 & - & - & 97 \\
\hline 40 & 40 & 27 & 38 & 25 & 7 & - & 97 \\
\hline Jumlah & 1.060 & 1.660 & 796 & 358 & 10 & 3.880 \\
\hline Nilai Skor & 5 & 4 & 3 & 2 & 1 & \\
\hline Total Skor & 5.300 & 6.640 & 2.388 & 716 & 10 & \\
\hline Grand total skor & & & & & & 15.054 \\
\hline $\begin{array}{l}\text { Rata-Rata Skor } \\
\text { Penelitian }\end{array}$ & & & & & & 376,35 \\
\hline Persentase & $27,31 \%$ & $42,78 \%$ & $20,51 \%$ & $9,22 \%$ & $0,25 \%$ & \\
\hline
\end{tabular}

Sumber : Data Olahan, 2018

Berdasarkan dan skor yang telah ditetapkan, akan dihitung jawaban dari

Berdasarkan tabel di atas dapat dilihat bahwa tanggapan responden mengenai persepsi masyarakat terhadap akad jual beli online perspektif Ekonomi Syariah di BKMT Kota Pekanbaru menyatakan setuju yaitu dengan persentase $42,78 \%$.

Berikut digambarkan persentase rekapitulasi perhitungan data angket menggunakan diagram lingkaran berdasarkan tabel di atas dapat dilihat pada gambar berikut ini :

\section{Diagram Lingkaran persepsi} masyarakat terhadap akad jual beli online perspektif Ekonomi Syariah di BKMT Kota Pekanbaru

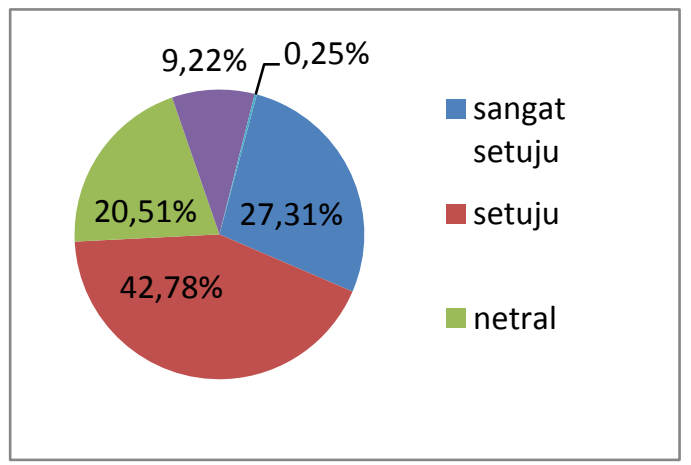
responden yang selanjutnya akan dibandingkan dengan skor ideal (kriterium) untuk seluruh item dan disajikan secara kontinum dalam gambar di atas sebagai berikut :

\section{Hasil Skor Penelitian Pada Garis Kontinum}

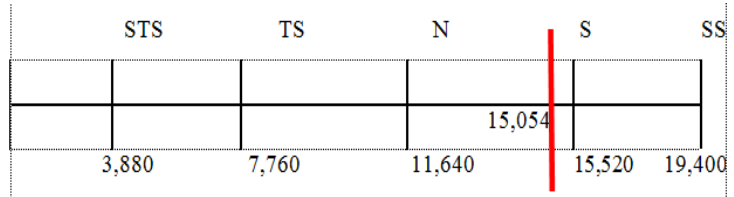

Namun jika dilihat dari perbandingan skor tertinggi dan skor penelitian $=19.400: 15.054$. Maka hasil skor penelitian pada garis kontinum terletak pada daerah "netral".

Jika dilihat dari nilai interpretasi skor penelitian yaitu 15.054/19.400x100 = 77, 59 \%. Maka dapat disimpulkan bahwa persepsi masyarakat terhadap akad jual beli online di BKMT Kota Pekanbaru dapat dikatakan "baik".

Sumber : Data Olahan 2018 


\section{SIMPULAN}

Berdasarkan hasil penelitian yang diungkapkan sebelumnya, maka dapat ditarik kesimpulan dan saran yang dapat penulis kemukakan sebagai berikut:

Berdasarkan dimensi "faktorfaktor eksternal" dari deskripsi di atas dapat disimpulkan bahwa responden telah memiliki gambaran faktor-faktor eksternal yang mempengaruhi persepsi masyarakat terhadap akad jual beli online dengan tingginya jawaban responden menyatakan setuju.

Berdasarkan dimensi "faktorfaktor internal" dari deskripsi di atas dapat disimpulkan bahwa responden telah memiliki gambaran faktor-faktor internal yang mempengaruhi persepsi masyarakat terhadap akad jual beli online dengan tingginya jawaban responden menyatakan setuju.

Dapat diambil kesimpulan bahwa tanggapan responden mengenai persepsi masyarakat terhadap akad jual beli online perspektif Ekonomi Syariah di BKMT Kota Pekanbaru menyatakan setuju yaitu dengan persentase $42,78 \%$.

Dilihat dari perbandingan skor tertinggi dan skor penelitian $=19.400$ : 15.054. Maka hasil skor penelitian pada garis kontinum terletak pada daerah "netral". Dilihat dari nilai interpretasi skor penelitian yaitu $15.054 / 19.400 \times 100=77,59 \%$. Maka dapat disimpulkan bahwa persepsi masyarakat terhadap akad jual beli online di BKMT Kota Pekanbaru dapat dikatakan "baik".

\section{DAFTAR RUJUKAN}

Abdul Rahman Ghazaly, Fiqh Muamalat, Jakarta, PT. Kencana Prenadamedia Group, 2010.
Bimo Walgio, Psikologi Sosial, Yogyakarta, Andi offset, 2002.

Departemen Agama, RI, Al-Qur'an dan terjemahan, Surabaya, CV Penerbit Fajar Mulia, 2009.

Didik M. Arief Mansyur \& Elisatris Gultom, Cyber Law (Aspek Hukum Teknologi Informasi), Bandung, Refika Aditama, 2005.

Kurnia. S. S, Jurnalisme Kontenporer, Jakarta, Yayasan Obor Indonesia, 2005.

Mardani, Fiqih Ekonomi Syariah, Jakarta, Kencana Prenadamedia Group, 2011.

Muhammad, Metodelogi Penelitian Ekonomi Islam, Pendekatan Kuantitatif, Ed, 1-1, Jakarta, Rajawali Pers, 2008.

Mardani, Fiqh Ekonomi Syariah, Jakarta, Kencana Prenadamedia Group, 2012.

Mardani, Hukum Perikatan Syariah di Indonesia, Jakarta, PT.Sinar Grafika, 2013.

Sulaiman Rasjid, Fiqih Islam, Bandung Sinar Baru Algensindo, 2012.

Taufik Hidayat, Buku Pintar Investasi Syariah, Jakarta Selatan, PT. Transmedia, 2011.

Wahbah Az-zuhaili, fiqih Islamwa adillatuhu. Jakarta, PT. Gema Insani,2011.

Yusuf Qardhawi, Halal Haram Dalam Islam, Surakarta, Era Intermedia, 2000. 